\title{
ЛІНГВІСТИЧНІ АСПЕКТИ ІНШОМОВНОЇ ПІДГОТОВКИ В УМОВАХ БАГАТОМОВНОСТІ
}

\begin{abstract}
Гаманюк В. А. Лінгвістичні аспекти іншомовної підготовки в умовах багатомовності.

У статті аналізуються лінгвістичні основи навчання іноземних мов в умовах багатомовності. Основна увага приділяється питанням формування індивідуальної багатомовності громадян за рахунок розвитку мовної уваги та трансферу мовних знань і навичок іншомовного навчання.

Ключові слова: дидактика багатомовності, трансфер, інтерференція, споріднені мови, мовна увага, мовна свідомість.
\end{abstract}

Гаманюк В. А. Лингвистические аспекты иноязычной подготовки в условиях многоязычия.

В статье анализаруются лингвистические основы обучения иностранным языкам в контексте многоязычия. Основное внимание уделяется вопросам формирования индивидуальной полилингвальности граждан за счет развития языкового внимания и трансфера лингвистических знаний, а также навыков изучения языков.

Ключевые слова: дидактика многоязычия, трансфер, интерференция, родственные языки, языковое внимание, языковое сознание.

Hamanyuk V. A. Linguistic Aspects of Foreign Languages' Education in the Context of Multilingualism.

The article discusses linguistic basis of teaching foreign languages in the context of multilingualism. The focus is on the formation of individual multilingualism of citizens through the development of linguistic attention and transfer of linguistic knowledge as well as skills in languages.

Key words: multilingualism didactic, transfer, interference, related languages, linguistic attention, languages awareness.

В умовах багатомовності постає питання ефективного навчання іноземних мов, формування індивідуальної багатомовності пересічних громадян, розширення лінгвістичного репертуару особистості та розвитку рецептивної компетенції. Досягти цього можна шляхом паралельного вивчення споріднених мов. Науковці, які досліджували це питання в рамках проекту EuroCom, дійшли висновку, що розпочинати слід насамперед 3 навчання читання кількома мовами. Тому перші підручники-довідники отримали назву «EuroComRom Сім сит: вміти читати романськими мовами одразу». Згодом з'явилися аналогічні підручники для германських та слов'янських мов. Таким чином були охоплені три найбільші у Європі мовні групи. Науковці вважають, що вивчення іноземних мов повинне відбуватися свідомо і 
тому в основу мають бути покладені базові лінгвістичні знання. Саме на грунті усвідомлення лінгвістичних спільностей та відмінностей споріднених мов відбувається формування $\mathrm{i}$ розвиток навичок рецептивного сприйняття інформації спорідненими мовами. Мовний контент було поділено на сім груп, які охоплювали всі рівні мови, а саме: на лексичному рівні систематизовано пангерманську лексику та інтернаціоналізми, на морфологічному - словотвірні можливості (спільні суфікси і префікси), а також засоби вираження граматичного значення у кожній з мов, на синтаксичному - синтаксичні структури, на фонетичному - фонетичні та графічні відповідності.

Розвиток полілінгвальної компетенції, яка вважається передумовою порозуміння в загальноєвропейському комунікативному просторі, перебуває в центрі уваги дослідників. Мовно-політична мета ЄC - рідна мова + дві іноземні - спонукає до вивчення проблеми багатомовної освіти не тільки 3 позиції організації, змісту та методики навчання іноземних мов як у межах інституційної освіти, так і у межах автономного навчання, але й з суто лінгвістичної точки зору. Детальному аналізу спільностей i відмінностей двох і більше споріднених мов, які могли б пришвидшити процес їх засвоєння присвятили свої дослідження науковці багатьох країн. Тож, актуальність проблеми не викликає сумніву, а вивчення досягнень зарубіжної дослідників у цих питаннях $\epsilon$ доцільним i корисним, зважаючи на євро інтеграційні прагнення України.

Одним із дієвих інструментів на шляху до індивідуальної багатомовності вважається дидактика багатомовності, теоретичні засади якої розробляються у Німеччині протягом останніх двох десятиліть провідними лінгвістами та фахівцями у сфері дидактики іншомовного навчання. Серед тих, хто долучився до системного вивчення проблеми та розробки концептуальних засад дидактики багатомовності й їх практичного втілення, слід назвати насамперед Х. Г. Кляйна, Ф.-Й. Майснера, . Хуфайзен, Т. Д. Штегмана в німецькому науковому просторі, Н. Свдокімову, Н. Баришнікова, В. Смокотіна у Росії, та Ю. Кажан і Л. Мороз в Україні.

Мета статті - проаналізувати лінгвістичні основи навчання іноземних мов в умовах багатомовності в контексті їх використання для формування індивідуальної багатомовності громадян за рахунок розвитку мовної уваги та трансферу мовних знань на прикладі проекту EuroCom.

Основи дидактики багатомовності як концепції розроблені Г.-Ю. Круммом, Г. Нойнером та Б. Хуфайзен. Дискусії щодо іiі 
розробки розпочалася через переорієнтацію процесу навчання на потреби тих, хто вчиться. Традиційна дидактика орієнтувалася на питання змісту і організації навчання, викладання і контролю знань. Цільова група розглядалася як гомогенна, а такі іï ознаки, як: віковий показник, походження, рівень освіти, мотивація, здібності - не бралися до уваги. Зміни у ставленні до вивчення мов, залучення до навчального процесу різних вікових категорій, навчання в гетерогенних групах стало поштовхом до пошуків нових підходів. Г. Нойнер зазначив, що для дидактики багатомовності, орієнтованої на потреби тих, хто вчиться, слід враховувати такі аспекти: наявність/відсутність в особи знань іноземних мов; індивідуальні потреби у вивченні мов; досвід їх вивчення; специфіка мовного профілю. 3 огляду на наявність знань хоч би однієї іноземної мови дидактика багатомовності виходить 3 того, що вивчення кожної нової мови не слід починати з нуля, а розвивати вже наявну іншомовну компетенцію, не варто спрямовувати зусилля на досягнення рівня носія мови, рівень компетентності та мовний профіль для кожної окремої мови теж можуть виявляти відмінності i залежатимуть від потреб [6].

3 позиції авторів дидактики багатомовності, зважаючи на попередній досвід вивчення мов, характерною ознакою людини $\epsilon$ мовленнєва здатність як цілісне поняття. Для навчання іноземних мов це означає: рідна мова має використовуватися і слугувати базисом при навчанні іноземних мов; при вивченні подальших мов слід спиратися на попередній досвід вивчення рідної (L1), першої (L2) та другої (L3) іноземних мов; слід зважати на індивідуальні особливості навчальної діяльності кожного i відповідно диференційовано підходити до організації навчального процесу; 3 огляду на рівень компетентності та мовний профіль кожного окремого учня, слід брати до уваги, що визначальними є потреби учнів.

До занять 3 рідної мови в контексті дидактики багатомовності висуваються певні вимоги. Серед них провідними Г. Нойнер називає: розвиток сенситивності до мови/мов і розвиток мовної свідомості (спочатку щодо рідної мови, а також через досвід контакту з іншими мовами в оточенні) та сприяння усвідомленню специфіки власного процесу навчання [6].

На передньому плані дидактики багатомовності з огляду на мету навчання є здатність до трансферу знань. Трансфер відбувається на рівні розиирення мовних знань за рахунок перенесення на грунт нової іноземної мови знань попередніх мов (схожі елементи, структури, граматичні форми, лексичні одиниці, слова-запозичення, 
інтернаціоналізми тощо, а також концентрація уваги на відмінностях, які слід узяти до уваги); розвитку навчальної свідомості через актуалізацію навчальних стратегій, техніки навчання та мовленнєвих стратегій.

EuroCom - концепція, що грунтується на паралельному вивченні споріднених мов. Х. Г. Кляйн, автор ідеї такого навчання, виходив 3 того, що майбутнє за рецептивними знаннями мов, саме вони $\epsilon$ ключовими компетенціями на сьогодні, тому що в умовах Інтернету доводиться насамперед читати тексти або сприймати інформацію на слух, що формує сталу потребу в навичках іншомовної рецепції в якомога більшій кількості іноземних мов. У подальшому ідеї Х.Г.Кляйна були покладені в основу концепції Ф.-Й. Майснера, механізм засвоєння кілька мов одночасно полягає у трансфері знань однієї мови на цілий ряд споріднених з нею за рахунок установлення зв'язків і виявлення схожих рис між ними. Навчання відбувається на основі тексту різними мовами. Проект EuroCom розроблено для різних мов, але для його ефективності слід готувати для роботи в його межах педагогічні кадри в умовах вищого навчального закладу [1, с. 33].

Ідея про впровадження навчальних модулів, де відпрацьовувалася б техніка рецептивного засвоєння мови, що грунтуються на когнітивному використанні інтра- та інтерлінгвальних знань та їх трансферу на грунт споріднених мов, стала поштовхом до започаткування у європейських країнах проектів, спрямованих на розвиток багатомовності. Такими орієнтованими на забезпечення потреб в іншомовній підготовці у професійній сфері проектами у Франції стали GALATEA та EUROM4, a в Німеччині EuroCom. EuroCom, скорочена форма поняття EuroComprehension, - акронім «Свропейське порозуміння» в межах трьох великих мовних груп Європи - романської, германської i слов'янської. Цими мовами як першою чи другою користуються майже всі європейці, а у проекції на весь світ вони охоплюють значну частину мешканців.

EuroComperhension як поняття в дослідженнях німецьких науковців розглядається як концепція (Ф.- Й. Майснер), як методика (Х. Г Кляйн, Т. Д. Штегман) і як теорія (Б. Хуфайзен). В Україні майже відсутні публікації, у яких висвітлювалися б основні положення відповідної концепції, у той час як у Росії виклад дидактичних засад EuroCom та специфіка вивчення споріднених мов розглядається у статтях Н. Баришнікова, Н. Евдокімової та В. Смокотіна.

Теоретичні засади концепції були викладені в низці наукових публікацій, у межах яких узагальнювалися результати досліджень та видавалися підручники-довідники 3 романських, германських та 
слов'янських мов у різних редакціях і різними мовами. Структура виданих підручників-довідників мало відрізняється і передбачає, окрім викладу концептуальних засад EuroCom, ще й опис кожної 3 мов групи (загальні відомості, особливості морфологічної, синтаксичної будови мов, словотвірні можливості, перелік загальновживаної лексики, суфіксів, префіксів тощо), відомості з історії мови, про поширеність мови у світі та іншу корисну інформацію. Існують видання EuroComRom (Х. Г. Кляйн, Т. Д. Штегман), EuroComGerm (Б. Хуфайзен, Н. Маркс), EuroComSlav (Л. Зібатов, Г. Зібатов).

Концепція EuroCom, як стверджує Х. Г. Кляйн, має розглядатися в мовно-політичній, мовнодидактичній та лінгвістичній площині. Мовно-політичний вимір (прагнення закріпити європейську багатомовність у структурі навчальних модулів та 3 орієнтацією на професійну діяльність і потребу в мобільності), упливає на розробку мовно-дидактичних концепцій (формування рецептивної іншомовної компетенції на засадах дидактики трансферу іншомовних знань), що, у свою чергу, спонукає до вивчення зв'язків, установлення спільностей і відмінностей між спорідненими мовами й використання результатів лінгвістичних досліджень у навчанні іноземних мов. Концепція розроблялася 3 огляду на три окреслені Єврокомісією перспективи подальшого розвитку іншомовного навчання: підтримку розвитку рецептивної багатомовності, реалізацію цільового формування окремих компетенцій 3 можливістю їх подальшого розвитку та свідоме використання зв'язків та схожостей споріднених мов (романських, слов'янських, германських) [4, с. 1].

Група дослідників, до якої входили Х. Г. Кляйн та Т. Д. Штегман, розробили методику, завдяки якій формуються рецептивні компетенції в усіх мовах романської групи. Після появи підручника «EuroComRom - Сім сит: вміти читати романськими мовами одразу» виникла потреба в теоретичному обгрунтуванні концепції та іiі застосуванні до двох інших груп мов, що найбільш широко представлені в мовному ландшафті Свропи, а саме: германської та слов'янської, а також розробити адекватні засоби інтерактивного навчання мов. На базі Заочного університету м. Хаген створено робочу групу фахівців «Шлях до багатомовності заочно», до якої увійшли спеціалісти у галузі романістики, германістики та славістики, а також фахівці у галузі інформатики. Уже у 2004 р. проектом було охоплено 12 університетів у шести країнах Свропи.

Мета методу EuroCom, на цьому наголошують його розробники, надати європейцям змогу стати багатомовними реальним шляхом, за 
рахунок формування рецептивних компетенцій, починаючи 3 розвитку навичок читання спорідненими мовами. Х. Г. Кляйн підкреслює, що EuroCom доводить кожному, що через знання рідної та лише однієї іноземної мови як представника групи споріднених мов уже закладено фундамент для подальшого розвитку індивідуальної багатомовності.

Пошук та усвідомлення відомих морфологічних елементів і синтаксичних структур уможливлюється за рахунок спорідненості мов, їх спільного минулого та схожих трансформацій у розвитку, а також за рахунок інтернаціоналізмів i запозичень. Схожості виявляються й на фонологічному рівні, на рівні графіки. Виходячи 3 цього, EuroCom виділяє сім мовних блоків, у межах яких у кожній новій іноземній мові, яка належить до певної групи (романських, германських або слов'янських), можна віднайти знайомі з рідної або знаної іноземної мови елементи. Ці сім блоків отримали влучну назву «сім сит» (die sieben Siebe). Через «сито» мовні явища просіюються, а в результаті виявляються спільні для цілої групи мов елементи, що сприяють засвоєнню вже не однієї, а кількох мов. Перше «сито» слова інтернаціоналізми, друге - лексика, наявна в усіх мовах групи (panromanischer, pangermanischer, panslavischer Wortschatz); третє фонетичні відповідності (схожість звучання слів у різних мовах та усвідомлення можливих фонетичних відхилень); четверте - установлення зв'язку між звуком та графічним знаком, який його позначає; п'яте загальні для мов синтаксичні структури; шосте - морфосинтаксичні структури (граматичні явища словозміни, словотвору); сьоме префікси і суфікси, здатні змінювати лексичне значення слова.

Підручники «EuroComRom», «EuroComGerm» i «EuroComSlav», створені на матеріалі романської, германської та слов'янської груп мов, дають змогу завдяки «фільтрації» семи сит виявити багато спільностей у цих мовах, а це, у свою чергу, реально наближає тих, хто вивчає мови, до рецептивної багатомовності. Уже через кілька занять той, хто навчається, здатен читати тексти всіма спорідненими мовами. Таким чином розвивається загальна лінгвістична компетенція, яка в подальшому може розширюватися за рахунок інших рецептивних або продуктивних компетенцій. Спочатку EuroCom зосереджувався саме на формуванні навичок читання, але згодом, завдяки розвитку інформаційних технологій, проект поширився і на розвиток навичок аудіювання.

EuroCom озброює і стратегіями розуміння, що грунтуються на трансфері знань. Це дає змогу за нетривалий час засвоїти кілька мов. Через сім сит просіюються лексика, граматичні явища, синтаксичні структури - усе те, що може підлягати трансферу. Традиційне 
навчання мови в системі освіти в контексті відповідної концепції видається неекономним, нераціональним й обмеженим, тому що вивчення кожної подальшої мови не враховує знань вивчених, не спирається на відомі навчальні техніки і стратегії, а це гальмує процес засвоєння мови, у той час як EuroCom, навпаки, мобілізує всі наявні ресурси і на їх грунті розширює мовний репертуар.

Унаочнити дієвість проекту можна на прикладі аналізу синтаксичних структур у германських мовах. У всіх германських мовах пангерманські синтаксичні структури становлять найвагомішу групу, хоч, як зазначають автори (Р. Бертеле), на відміну від романських мов, германські навіть у цій сфері виявляють багато відхилень, які все ж не перешкоджають адекватно зрозуміти зміст. Виділяються 16 синтаксичних структур, які є спільними для германських мов, що можна унаочнити прикладами 3 німецької та англійської мов:

\begin{tabular}{|c|c|c|}
\hline 1. & 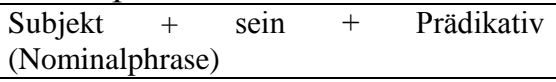 & $\begin{array}{ll}\text { нім. } & \text { Sie ist Studentin. } \\
\text { англ. } & \text { She is (a) student. }\end{array}$ \\
\hline 2. & Subjekt + sein + Prädikativ (Adjektiv) & $\begin{array}{l}\text { нім. Sie ist glücklich. } \\
\text { англ. She is happy. }\end{array}$ \\
\hline 3. & $\begin{array}{l}\text { Subjekt }+ \text { sein }+ \text { Prädikativ (Adjektiv) }+ \\
\text { Vergleichspartikel + Nominalphrase }\end{array}$ & $\begin{array}{ll}\text { нім. Sie ist schneller als du. } \\
\text { англ. She is faster then you. }\end{array}$ \\
\hline 4. & Subjekt + Prädikat & $\begin{array}{l}\text { нім. Sie arbeitet. } \\
\text { англ. She works. }\end{array}$ \\
\hline 5. & Subjekt + Prädikat + Objekt & $\begin{array}{l}\text { нім. Sie schreibt einen Brief. } \\
\text { англ. She writes a letter. }\end{array}$ \\
\hline 6. & $\begin{array}{llll}\text { Subjekt } & + & \text { Prädikat } & + \\
\text { Umstandsbestimmung } & & \end{array}$ & $\begin{array}{l}\text { нім. Sie schwimmt im Fluß. } \\
\text { англ. She swims in the river. }\end{array}$ \\
\hline 7. & $\begin{array}{l}\text { Subjekt }+ \text { Prädikat }+ \text { Objekt }+ \\
\text { Umstandsbestimmung }\end{array}$ & $\begin{array}{l}\text { нім. Sie schreibt einen Brief im } \\
\text { Zimmer. } \\
\text { англ. She writes a letter in the room. }\end{array}$ \\
\hline 8. & $\begin{array}{l}\text { Subjekt }+ \text { Prädikat }+ \text { Objekt }+ \text { Objekt }+ \\
\text { Umstandsbestimmung }\end{array}$ & $\begin{array}{l}\text { нім. Sie schreibt ihm einen Brief im } \\
\text { Zimmer. } \\
\text { англ. She writes him a letter in the } \\
\text { room. }\end{array}$ \\
\hline 9. & $\begin{array}{l}\text { Fragewort }+ \text { Prädikat }+ \text { Objekt oder } \\
\text { Nominalphrase }\end{array}$ & $\begin{array}{l}\text { нім. Wer arbeitet? } \\
\text { англ. Who works? } \\
\text { нім. Wer hat Zeit? } \\
\text { англ. Who has time? } \\
\text { нім. Wen siehst du? } \\
\text { англ. Who do you see? }\end{array}$ \\
\hline 10 . & {$[$ Konnektor $]+$ Subjekt + Prädikat $+[\ldots]$} & $\begin{array}{l}\text { нім. Und sie schreibt [einen Brief im } \\
\text { Zimmer]. } \\
\text { англ. And she writes [a letter in the } \\
\text { room]. }\end{array}$ \\
\hline 11. & Prädikat + Subjekt + Objekt & $\begin{array}{l}\text { нім. Nimmt sie das Buch? } \\
\text { англ. Does she take the book. }\end{array}$ \\
\hline
\end{tabular}




\begin{tabular}{|c|c|c|}
\hline 12. & Prädikat + Eränzung(en) & $\begin{array}{l}\text { нім. Geh in dein Zimmer! } \\
\text { англ. Go to your room! } \\
\text { нім. Nimm dieses Buch! } \\
\text { англ. Take this book! } \\
\text { нім. Leg das Buch auf den Tisch! } \\
\text { англ. Put the book on the table! } \\
\text { нім. Gib mir das Buch! } \\
\text { англ. Give me the book! }\end{array}$ \\
\hline 13. & {$[\ldots]+$ Prädikat } & $\begin{array}{l}\text { нім. [Ich habe alles], was ich brauche. } \\
\text { англ. [I have all] what I need. }\end{array}$ \\
\hline 14. & $\begin{array}{l}\text { Subjekt }+ \text { Verb (finit) }+ \text { Objekt }+[\ldots]+ \\
\text { Verb (infinit) (нім.) } \\
\text { Subjekt }+ \text { Verb (finit) }+ \text { Verb (infinit) }+ \\
\text { Objekt }+[\ldots] \text { (англ.) }\end{array}$ & $\begin{array}{l}\text { нім. Ich habe den Brief geschrieben. } \\
\text { англ. I have written the letter. }\end{array}$ \\
\hline 15. & $\begin{array}{l}\text { Verb (finit) }+ \text { Subjekt }+ \text { Objekt }+[\ldots]+ \\
\text { Verb (infinit) }(\text { нім.) } \\
\text { Verb (finit) }+ \text { Subjekt }+ \text { Verb (infinit) }+ \\
\text { Objekt }+[\ldots] \text { (англ.) }\end{array}$ & $\begin{array}{l}\text { нім. Hast du den Brief geschrieben? } \\
\text { англ. Have you written the letter? }\end{array}$ \\
\hline 16. & $\begin{array}{l}\text { Subjekt + Verb (finit) [+Adverb] + Verb } \\
\text { (infinit) + Objekt (англ.) } \\
\text { Subjekt + Verb (finit) + Objekt } \\
\text { Adverb] + Verb (infinit) (нім.) }\end{array}$ & $\begin{array}{l}\text { англ. I have [already] written the } \\
\text { letter. } \\
\text { нім. Ich habe den Brief [noch gestern] } \\
\text { geschrieben. }\end{array}$ \\
\hline
\end{tabular}

У таблиці курсивом позначені ті випадки, коли реалізація синтаксичної моделі у двох споріднених мовах виявляє невідповідності. Очевидно, що німецька та англійська мови виявляють на рівні синтаксичних структур багато спільностей. Невідповідності наявні лише в тому разі, коли в реченні є складний присудок. У німецькій мові складний присудок утворює рамку, відповідно на другому місці в реченні стоїть Verb (finit.), а на останньому - Verb (infinit.). Рамкова конструкція відсутня в англійській мові, хоч присутня ще в деяких германських мовах. Зважаючи на те, що розуміння речення починається 3 визначення підмета та присудка в усіх його можливих варіантах, акцентування уваги на синтаксичних особливостях мов, що вивчаються, виявлення та усвідомлення спільностей та розбіжностей у них є дуже важливим.

Ще більше невідповідностей дві споріднені мови виявляють на рівні морфології. У німецькій мові граматичне значення реалізується насамперед за рахунок синтетичних засобів вираження граматичного значення, у той час як в англійській використовуються переважно аналітичні. Проілюструвати це можна на прикладі відмінювання іменників, прикметників, утворення різних форм дієслова: 


\begin{tabular}{|c|c|c|}
\hline нім. & англ. & укр. \\
\hline $\begin{array}{l}\boldsymbol{e} \text { ein schönes Mädchen } \\
\text { mit einem schönen Mädchen }\end{array}$ & $\begin{array}{c}\text { a good girl } \\
\text { with a good girl }\end{array}$ & $\begin{array}{c}\text { гарна дівчина } \\
3 \text { гарною дівчиною } \\
\end{array}$ \\
\hline $\begin{array}{c}\text { das neue Kleid } \\
\text { des neuen Kleides } \\
\text { in dem neuen Kleid }\end{array}$ & $\begin{array}{l}\text { the new dress } \\
\text { the new dresses } \\
\text { in the new dress }\end{array}$ & $\begin{array}{c}\text { нова сукня } \\
\text { нової сукні } \\
\text { у новій сукні }\end{array}$ \\
\hline $\begin{array}{c}\text { Ich schreibe einen Brief. } \\
\text { Du schreibst einen Brief. } \\
\text { Er schreibt einen Brief. } \\
\text { Ich habe einen Brief geschrieben } \\
\text { Du hast einen Brief geschrieben. } \\
\text { Du schriebst einen Brief } \\
\text { Er schrieb einen Brief. }\end{array}$ & $\begin{array}{c}\text { I write a letter. } \\
\text { You write a letter. } \\
\text { He writes a letter. } \\
\text { I have written a letter. } \\
\text { You have written a letter. } \\
\text { You wrote a letter. } \\
\text { He wrote a letter. }\end{array}$ & $\begin{array}{c}\text { Я пишу листа. } \\
\text { Ти пишеш листа. } \\
\text { Він пише листа. } \\
\text { Я написав листа. } \\
\text { Ти написав листа. } \\
\text { Ти писав листа. } \\
\text { Він писав листа. }\end{array}$ \\
\hline
\end{tabular}

3 таблиці видно, що в німецькій мові значно більше формальних показників вираження граматичного значення, ніж в англійській. Відсутні показники роду іменників, артиклі в англійській мові не мають відмінкових форм, іменники мають формальне вираження лише для множини та родового відмінка, дієслова мають відмінні форми лише у третій особі однини в теперішньому часі, i спільні форми дієслова to write у Past Indefinite, а у Present Perfekt різні форми дієслова to have для третьої особи однини та для решти особових форм однини й множини. У німецькій мові формальні показники передбачені для протиставлення граматичних форм роду $\mathrm{i}$ відмінка артикля, іменника й прикметника, для особових форм дієслів у теперішньому та минулому часі. Наявність таких розбіжностей, безумовно, ускладнює процес паралельного засвоєння цих двох германських мов, але, 3 іншого боку, - закладає лінгвістичний фундамент для вивчення інших мов цієї групи.

У цьому контексті постає питання, наскільки грунтовною має бути лінгвістична підготовка при паралельному вивченні двох i більше мов. Очевидно, що таке вивчення потребує впевненого володіння термінологією, розуміння ключових лінгвістичних понять. Зрозуміло, що створити міцну лінгвістичну основу лише у процесі вивчення іноземних мов досить складно, тому розпочинати цей процес слід ще під час навчання рідної мови. Від цього напряму залежатиме спроможність вивчати іноземні мови і піддавати аналізу притаманні їм мовні явища. Адже трансфер мовних знань неможливий за їх відсутності.

Отже, узагальнюючи досвід навчання споріднених мов у межах проектів EuroComSlav, EuroComGerm, EuroComRom, можна зробити такі висновки. Іноземні мови та практика їх навчання перебувають 
сьогодні у центрі уваги і теоретиків, і практиків мовної освіти, а також посадовців у освітній сфері. Метою іншомовної освіти $\epsilon$ формування індивідуальної багатомовності, яка $є$ передумовою багатомовності суспільної, а досягти поставленої мети можна лише за умови залучення якомога більшої кількості громадян до вивчення іноземних мов i спрощення процесу їх засвоєння. Дидактика багатомовності взагалі, і паралельне вивчення споріднених мов зокрема відкривають нові горизонти в цій справі. Проект EuroCom, доступним через мережу Інтернет, $\epsilon$ теоретично $i$ методично обгрунтованим, забезпечує не тільки безперешкодний доступ до інформації, але й озброює навчальними стратегіями, які покликані мобілізувати всі наявні механізми свідомого засвоєння споріднених мов, трансферу мовних знань і навичок вивчення попередніх мов, включаючи рідну мову та мову оточення на основі концентрації уваги на лінгвістичних спільностях та відмінностях. Подальшого дослідження потребують насамперед лінгводидактичні засади навчання другої та третьої іноземної мови, тому що в Україні в системі освіти вивчаються германські мови (англійська та німецька), тож використання досвіду проекту EuroComGerm $є$ доцільним і має перспективи запровадження як у межах організованого, так i автономного навчання.

\section{Література}

1. Hufeisen B. Fit für Babel / B. Hufeisen // Gehirn und Geist. - 2005. - № 6. - S. 28-33.

2. Hufeisen B. Mehrsprachigkeitskonzept - Tertiärsprachenlernen - Deutsch nach Englisch / B. Hufeisen, G. Neuner. - Strasbourg : Europarat, 2003. - 248 S.

3. Hufeisen B. EuroComGerm - Die sieben Siebe : Germanische Sprachen lesen lernen / B. Hufeisen, N. Marx. - Aachen : Shaker, 2007. - 370 S.

4. Klein H. G. Neue Wege zur Mehrsprachikeit in Europa : Eurocomprehension [Електронний pecypc] / H. G. Klein. - Режим доступу : www. eurocomresearch.net/lit/innsbruck.pdf.

5. Klein H. G. EuroComRom - Die sieben Siebe : Romanische Sprachen sofort lesen können / H. G. Klein, T. D. Stegmann. - Aachen : Shaker, 2000. - 287 S.

6. Neuner G. Mehrsprachigkeitsdidaktik und Tertiärsprachenlernen: Grundlagen Demensionen - Merkmale : [Електронний pecypc] / G. Neuner. - München : Hueber, 2009. - Режим доступу : www.hueber.de/mehrsprachigkeitsdidaktik

Стаття надійшла до редакції 16.11 .2013 р. 